Carrie A. Blair ${ }^{1}$ / Kelly G. Shaver ${ }^{2}$

\title{
Of Horses and Jockeys: Perceptions by Academic Entrepreneurs
}

\author{
${ }^{1}$ College of Charleston, Department of Management and Marketing, School of Business, Charleston, SC, United States of \\ America. https://orcid.org/0000-0001-9257-6928. \\ ${ }^{2}$ College of Charleston, Department of Management and Marketing, School of Business, Charleston, SC, United States of \\ America, E-mail: kelly.shaver@gmail.com. https://orcid.org/0000-0002-0699-374X.
}

\begin{abstract}
:
Although there has been increasing recent interest in universities as ecosystems for the encouragement of academic entrepreneurship, almost none of that work has dealt with the specific personal motives that might lead academic scientists to start companies. Metaphorically, there has been a substantial body of work describing how to create a better racetrack, some study of what sort of horses best perform in the track, but essentially no examination of the jockeys. We address this gap in the literature in two ways - first by "importing" a variety of psychological characteristics that have been shown to be predictive in the larger entrepreneurship literature, and second by developing a series of context-specific motives. Our study of 50 biomedical scientists in an academic medical center showed, unsurprisingly, that patents matter. More importantly, although the results for the imported psychological characteristics were disappointing, the findings for context-specific motives suggest that founders are distinguished from non-founders primarily by their interest in doing something positive for humanity.
\end{abstract}

Keywords: academic entrepreneurship, cognitive processes, individual motives

DOI: 10.1515/erj-2019-0011

\section{Introduction}

Venture investors are known for taking a portfolio approach to their work: Pick multiple companies as investment targets with the full expectation that not all will succeed, but with the fervent hope that at least a few will scale and perform so well that their success will more than cover the losses. Indeed, this is the heart of Wilson's well-known "1/3-1/3-1/3" model (e.g., 2008) for venture capital investments: Expect that one third of the investments will be total losses, another third will cover their costs but fail to return profits, and the final third will include some stars that perform so well that they allow the fund as a whole to return an annualized $20 \%$ on its investments. Similarly, rather than attempting to "pick winners," cities, universities, and private investors are creating incubators, accelerators, and co-working spaces (the phenomenal growth of WeWork is merely one example) for multiple companies at a time. But unless an incubator or accelerator has substantial institutional backing, or charges enough of an admission fee to recover its cost and make a fair profit, it must depend on the future success of its participating companies.

In short, like venture capitalists, incubators must also adopt a portfolio model. As a result, private-sector facility directors, and even city economic development officers, put their hopes on some form of ecosystem that will, over time and changing tenants, produce the desired returns. Lost in this process is attention to the personal characteristics, plans, and motives of the individuals who become entrepreneurs. In the well-worn horse-racing metaphor, the various planners are spreading their bets across a large number of horses, while overlooking the particular jockeys (despite the oft-stated claim of venture investors that they bet on the jockey, not the horse). The primary contribution of this paper is to argue that the perceptions held by individual entrepreneurs still matter a great deal. Specifically, we compare the perceptions of biomedical scientists who have founded companies to biomedical scientists who have not founded companies. We first draw on the Theory of Planned Behavior (TPB; Ajzen 1985) that has been used previously in the study of academic entrepreneurs. Next, we turn to self-efficacy (Bandura 1977, 2012) and other psychological characteristics frequently seen in the entrepreneurship literature. We conclude with reasons to commercialize that are specific to the biomedical context. Perhaps not surprisingly, these are the ones that matter the most. 


\section{University Commercialization Efforts}

A major step in the increasing economic responsibility of the American university was the passage in 1980 of the Government Patent Policy Act of 1980 (Public Law 96-517), now popularly known as the Bayh-Dole Act. Prior to Bayh-Dole, patent rights to inventions funded by grants from the federal government were retained by the government and the pathways to commercialization were often obscure. The effect of Bayh-Dole was to transfer the responsibility for commercialization to the university or company that had received the federal support. At this point, universities developed technology transfer offices (TTOs), implemented patent policies, and began to consider licensing revenues as an important source of funding for the institution. Indeed, Thursby and Thursby (2011b) note that the number of TTOs increased from 25 in 1980 to over 230 in 2004. A special issue of Research Policy was published in 2011 to commemorate the 30th anniversary of Bayh-Dole (Grimaldi et al. 2011); a subsequent special issue of Economic Development Quarterly (Audretsch, Link, and Peña-Legazkue 2013) addresses the relationship between university commercialization and regional economic development, though only one of the papers deals with individual faculty members, and then only with whether they have grant-supported publications co-authored with industry collaborators (Banal-Estañol, Macho-Stadler, and Pérez-Castrillo 2013).

As a number of writers have noted, the passage of Bayh-Dole dramatically changed many of the institutional norms (Bercovitz and Feldman 2008; Jain, George, and Maltarich 2009; Owen-Smith and Powell 2001; Stuart and Ding 2006). One can imagine several changes that might be negative. As an example, as now informally recognized in (conflicting) Federal research guidelines, rules for required reporting of research outcomes ("data sharing") exist side by side with rules that require the reporting of any potential financial conflict of interest, explicitly including any level of equity ownership in a start-up company (National Science Foundation Investigator Financial Disclosure Policy 59 FR 33,308; Public Health Service requirements 42 CFR 50 and 45 CFR 94). It is worth mentioning financial conflict of interest regulations in an article about the motivations of academic entrepreneurs because these regulations might be perceived as "another reason not to commercialize."

Despite some potential internal policy misalignment, a university-based venture development organization (VDO) can have several advantages over incubators and accelerators that are not part of a university. Specifically, the university-based VDO has access to a variety of resources that would be expensive or unattainable on the open market. Experts in almost any field are minutes away, if not physically "down the hall." Student interns are easily available. Some needs of the resident companies can be satisfied by class projects that also provide students with valuable hands-on experience. Financial and personnel operations of the VDO simply get rolled into the existing administrative structures of the university. Even space to be occupied by the VDO can often be created without the need to leave campus (though some universities have created their own technology development parks, open to the university community and the private sector as well).

A university VDO would have yet another advantage: a pool of faculty whose research products are ready for commercialization. The faculty seek external grant support to fund their research - already an entrepreneurial activity when funding success rates are in the very low double digits. The faculty decide whether to report invention disclosures to their TTOs. Finally, faculty determine whether it makes sense for them to create companies or instead to license the intellectual property they have created to an existing company. Certainly, it is true that the institution technically owns the intellectual property, but it is just as certain that without the activities of the faculty there would be no intellectual property to own.

Still, numerous writers have pointed out that a preponderance of literature on "academic entrepreneurship" has concentrated on institution-level outcomes (disclosures, patents, licenses, companies formed) rather than on the people who have produced the foundation on which those results rest (Aldridge and Audretsch 2011; Clarysse, Tartari, and Salter 2011; Link, Siegel, and Bozeman 2007). Even when the individual faculty members are the presumed subject of research, we agree with Clarysse, Tartari, and Salter (2011) that " ... the extant literature on academic entrepreneurship has pre-dominantly [sic] focused on social environmental factors to explain entrepreneurial behavior, while not addressing ... individual attributes" (p. 1085). Regardless of the particular form of university-based venture development activity undertaken, there is general recognition that commercialization begins with what Krabel and Mueller (2009) call the "importance of scientists' personal incentives" (p. 947). In an extensive review of technology commercialization, Allen (2012) called for increased research attention to a variety of issues, including "Are there intrinsic motivators for scientists to become engaged in commercialization activities? This would contribute to our limited understanding of what motivates scientists" (p. 15).

Recently, there has been a dramatic increase in research on academic entrepreneurship, including special issues of Small Business Economics (Guerrero et al. 2016) and the Journal of Management Development (Caiazza, Shane, and Ferrara 2017), as well as several studies on particular motivations like the "mission" of the university (Iorio, Labory, and Rentocchini 2017), the perceived norms in the home department (Kalar and Antoncic 2015), or attitudes toward commercialization (Wu, Welch, and Huang 2015). Yet it is true as Nicolaou and Souitaris (2016) note that, " ... despite the growth in the size and the quality of the literature, we still know 
little about what keeps academic inventors in the university, in the face of spinouts ... " (p. 301). To that assertion we would add that particularly little is known about the psychological factors that drive individual academic entrepreneurs. This paper aims to make three contributions to the literature. First, we review work that has attempted to understand the individual academic entrepreneurs, and use it to first clarify a definition of the academic entrepreneur. Second, we argue that no matter what metrics are adopted by university-based VDOs, the success of the organization will in no small part depend on the motivations of the participating academic entrepreneurs. Third, we present data on a set of university employees to look for patterns of motives that differentiate academic biomedical scientists who are entrepreneurs from those who are not academic entrepreneurs.

\section{Who Is An Academic Entrepreneur?}

There is a continuing conversation in the entrepreneurship literature on what, exactly, are the defining characteristics of "an entrepreneur." Can there be "entrepreneurs" working in Fortune 100 companies? Is an MBA student member of a winning business plan competition team an "entrepreneur?" Is the founder of a failed business an "entrepreneur?" What is the difference between "an entrepreneur" and a "small business owner?"

Especially in an academic setting, it is important to have a fairly restrictive definition of what constitutes "an entrepreneur." Why should this be the case? Consider one of the classic definitions of an entrepreneur: A person who, on his or her own or inside an organization, pursues opportunity without regard to resources currently under control (Stevenson and Jarillo 1990; Stevenson, Roberts, and Grousbeck 1989). Now examine the behavior of any academic scientist: Investigating problems for which there is no current answer, writing papers for submission to journals with $90 \%$ rejection rates, seeking grant support in a climate where success rates in the low double digits are considered "good." Consequently, a definition couched only in the discovery and exploitation of opportunities is likely to include so many academic scientists that it loses its value as a classification device.

Rather than attempting to mediate among the possible conceptual definitions of an entrepreneur, we choose to employ a much more restricted operational definition beginning with the one used in the Panel Studies of Entrepreneurial Dynamics (PSED; Gartner et al. 2004; Reynolds and Curtin 2009). Specifically, we define an academic scientist as an "entrepreneur" if four conditions hold, the first three of which are from the PSED. First, the person must - alone or with others - have created a new business (a scientist who is currently in the process of doing so would be a "nascent" entrepreneur). Second, the academic scientist must expect to own equity in the business. Third, the academic scientist must have undertaken some business-related activities within the past 12 months. A final condition is added to the three from the PSED: The academics need to remain in the employ of their universities (Nicolaou \& Birley's 2003 "hybrid" firm). In the present study, however, our interest is to compare academic entrepreneurs to academics who do not start firms of any sort.

\section{Patents}

There is one immediate implication of our definition: Patents count, but patents alone do not define a scientist as an "academic entrepreneur." In the literature on academic entrepreneurship, particularly that segment of the literature that examines the effectiveness of university TTOs, patent activity is often a primary measure of the university's commercial activity (Geuna and Rossi 2011; Link, Siegel, and Van Fleet 2011). Patents, together with numbers of inventions disclosed (e.g., Thursby and Thursby 2011a), numbers of spin-off companies created (Di Gregorio and Shane 2003; Fini et al. 2011; Kenney and Patton 2011), numbers of incubator tenants (e.g., Clarysse et al. 2005), and even numbers of faculty members who participate on scientific boards of private companies (Stuart and Ding 2006) certainly indicate the extent to which a university participates in business activities. But as Aldridge and Audretsch (2011) noted, patent activity - at least as reported in data from the Association of University Technology Managers (AUTM) - is typically aggregated at the level of the TTO, effectively obscuring the patent activity of individual faculty members. Even when patents are examined at the level of the individual, as in the case of research by Prodan and Drnovsek (2010), we would argue that a patent does not signify academic entrepreneurship unless it is done in the presence of a company founded by, or at least partially owned by, the patent holder, as in the case of the Max Planck scientists studied by Krabel and Mueller (2009).

The definitional issue is present in a frequently cited paper (Stuart and Ding 2006) that has the enticing title "When do scientists become entrepreneurs?" This research addresses the normative beliefs held in the scientist's department and university, from the standpoint of reference group theory (Hyman 1942; Kelley 1952; 
Merton 1957). The basic argument is that academic scientists will take cues from their immediate social environments and will - to one degree or another - behave accordingly (Chang et al. 2016). Stuart \& Ding's results showed that the "academic entrepreneurs" in their sample had more extensive lists of publications than did their non-entrepreneurial colleagues. Unfortunately, Stuart \& Ding included individuals who were members of Scientific Advisory Boards (SABs) along with founders of public companies in the category of "academic entrepreneurs." Indeed, their original sample (before deletion of medical doctors and those with PhD degrees from non-US universities) contained roughly five SAB members for every one company founder. Because the data were combined for founders and SAB members, it is impossible to rule out the possibility that, for example, there is a sub-cohort publication difference with SAB members producing more publications per person than do company founders.

To avoid this problem, we limit the term "entrepreneur" to the founder of a company. Just holding a patent while remaining in one's university laboratory, filing invention disclosures with no intention of following them up, becoming an SAB member, and serving as a paid (and sometimes even indemnified) consultant to a start-up company does not make one an entrepreneur. In short, if the study of commercialization originating from VDOs is to align with current practice in the larger entrepreneurship literature, it will need to define an entrepreneur as a founder. Otherwise the entrepreneurial behavior of the university itself will be impossible to distinguish from the entrepreneurial action of its individual faculty members. Consequently, we compare the perceptions of biomedical scientists who have founded companies to biomedical scientists who have not founded companies. Much of the research on the correlation between publication and grant receipt deals with the publications that follow grant funding, but one by Kaltman et al. (2014) does show the predictive value of publication prior to grant funding.

In another study, Prodan and Drnovsek asked about the academic's personal networks, number of years spent at academic institutions, number of academic entrepreneurs personally known, level of cooperation with industry, and number of patents held. The researchers then contacted 1,708 members of technical faculties at the University of Ljubljana and the University of Cambridge, obtaining a valid response rate of $32 \%$. Among other things, the results showed entrepreneurial self-efficacy related to entrepreneurial intentions, and those intentions positively related to personal networks, perceived role models, and number of patents. Unfortunately, from our present perspective, Prodan and Drnovsek eliminated from consideration the 48 respondents who already had their own companies. Where patents are concerned, the authors' Hypothesis 7 stated that the number of patents filed and/or granted "is positively related to academic-entrepreneurial intentions" (p. 335). That hypothesis was confirmed. Consequently, we propose:

H1: Biomedical scientists who have founded companies will have more patents than biomedical scientists who have not founded companies.

\section{Planned Behavior}

Recognizing that the creation of a new business venture, even as a spin-off from a university, requires time and planning, there has been substantial interest in the development of entrepreneurial intentions (e.g., Fayolle and Liñán 2014; Liñán and Chen 2009). There are two popular theoretical alternatives for examining entrepreneurial intentions. These are the TPB (Ajzen 1985) and the entrepreneurial event model (EEM; Shapero \& Sokol, 1982), but the former is by far more common in the academic entrepreneurship literature. We will limit our discussion to the TPB, despite recent research suggesting it might be combined with EEM (Schlaegel and Koenig 2014).

The TPB holds that there are three major determinants of behavioral intentions. The first of these is the person's general attitude toward the behavior in question (PA). Without a positive attitude, nothing else matters, so a faculty member for whom commercialization is of minor importance will not develop entrepreneurial intentions. (One can imagine that if the only institutional rewards - including tenure - are based exclusively on publications and research grants there will be little desire to commercialize research discoveries, a point also made by Mosey, Wright, and Clarysse 2012.) The second influence on entrepreneurial intentions is the subjective norms (SN) perceived by the potential entrepreneur. These social norms can be seen in some of the reference group studies described above and in recent work on the entrepreneurial orientation (EO) of university departments (Kalar and Antoncic 2015). The third element affecting entrepreneurial intentions is perceived behavioral control (PBC), which is sometimes separated into two parts: perceived self-efficacy given the opportunity, and controllability (by anyone). The three elements of the TPB are normally considered to combine multiplicatively, in the sense that if any element has a zero value, there will be no entrepreneurial intention.

One important study on entrepreneurial intentions of academic scientists (Goethner et al. 2012) combined a sophisticated assessment of all elements of the TPB with dependent variables that included the founding 
of a company. These investigators combined insights from economic research on academic entrepreneurship with psychological characteristics. For an academic entrepreneur-to-be, human capital includes all of those years of becoming an expert. The scientist's social capital not only includes colleagues and a substantial withinacademia network but also ties to industrial partners and government agencies. Specifics of the economic approach argue that the transition to entrepreneurship will occur "when the expected future profits from becoming an entrepreneur are larger than the sum of expected future benefits from employed work" (p. 630). The research included measures of human capital, social capital (industry cooperation, public support institutions), expected benefits (reputational gain and financial gain), and an assessment of components of the TPB (attitudes, social norms, PBC). Results of a path model showed positive effects for both TPB attitudes and TPB PBC on entrepreneurial intentions. A follow-up survey 18 months later obtained information on company founding from 219 of the participants; the three standardized TPB variables predicted subsequent creation of companies.

A second study in the intentions framework by Guerrero and Urbano (2014) addressed the issue of why so relatively few academic scientists actually start a company. The work was grounded in the knowledge spillover theory of entrepreneurship (Acs et al. 2009). Because entrepreneurship is the means by which knowledge spillover is translated into competitive advantage and economic growth, entrepreneurship ought to be especially prevalent in contexts where investments in the generation of new knowledge are high (e.g., in academic settings). Guerrero and Urbano (2014) suggest that elements of individual motivation best described by the TPB might act as one of the "knowledge filters" that stands between the research investment and the creation of entrepreneurial companies. University policies can also be seen either as promoting or reducing PBC. Results of the study suggested that lack of PBC, in the form of lack of confidence in one's ability to execute the tasks required for beginning an entrepreneurial venture, predicts failure to create entrepreneurial companies.

A final study in this vein, by Knockaert et al. (2015), made the assessment of entrepreneurial intentions more specific by emphasizing growth intentions. As contrasted to "entrepreneurial intentions," growth intentions predict post-founding growth (Delmar and Wiklund 2008; Douglas 2013) and are especially important for university spin-offs (Zhang 2009). A second unique feature of this article is its use of a multidimensional cognitive style variable to represent the individual's preferences among creating, planning, and knowing, the Cognitive Style Indicator (CoSI: Cools and van Den Broeck 2007). Among other things, the results of the study showed that (a) SN were positively related to entrepreneurial intentions, (b) the knowing style was negatively related to entrepreneurial intentions and to growth intentions, (c) the planning style was positively related to growth intentions, but surprisingly, (d) the creating style was not significantly related to growth intentions. Given that spin-off companies from entrepreneurial universities are typically expected to grow enough to justify the university's patent costs - not to mention contribute to a future royalty stream or equity position - the study of growth intentions is an important area to continue. Taken together, these studies of entrepreneurial intentions suggest the following hypothesis:

H2. Psychological characteristics related to the TPB model will be stronger among biomedical entrepreneurs than among biomedical scientists who have not founded companies.

\section{Self-Efficacy and Expectancy}

Several studies have examined what are often called the "personal characteristics" associated with academic entrepreneurship. But unfortunately, many of the truly psychological attributes are either missing or treated as control variables in these studies rather than serving as the focal variables of interest.

For example, Boardman and Ponomariov (2009) employed a "national survey" of tenured and tenure track research scientists to examine personal and professional characteristics related to participation with industry. Note that this was engagement, not entrepreneurship. Interestingly, from our perspective, this survey specifically excluded academic scientists located in Historically Black Colleges and Universities (HBCUs) and in universities in US states identified by the National Science Foundation as needing special consideration to enhance their ability to do nationally competitive research (the Established Program to Stimulate Competitive Research - EPSCoR - program). Moreover, the "personal characteristics" were limited to sex, age, a question asking whether commercialization distracts one from doing good research, and a preference for doubling one's publication rate versus doubling one's salary.

Although gender was included in the Boardman and Ponomariov study (2009), that is an anomaly in the literature on academic entrepreneurship. A number of articles in the area fail to control for (or sometimes even mention) the gender of participants in their research (Bercovitz and Feldman 2008; Mosey and Wright 2007; Prodan and Drnovsek 2010; van Burg and van Oorschot 2013). On the one hand, the absence of women in research on academic entrepreneurship could be explained by the relative absence of women in the STEM fields most heavily involved in technological commercialization. On the other hand, 
it is worth noting that well over a third of bioengineering doctorates in the US are now earned by women (https://www.nsf.gov/statistics/2017/nsf17306/data/tab16.pdf). In the future, we hope to see gender as a source of comparison rather than exclusively as a dummy variable used for control purposes.

One of the personality factors frequently implicated in entrepreneurial success is self-efficacy (Bandura 1977, 2012). In general, a person's self-efficacy reflects his or her ability to handle life's challenges. Outside the academic setting, self-efficacy is a consistent predictor of performance (Judge and Bono 2001; Stajkovic and Luthans 1998), satisfaction (Judge and Bono 2001), and other work-related criteria. One meta-analysis found the average estimated correlation between self-efficacy and performance to be 0.38 , which represents a $28 \%$ gain in performance based on self-efficacy. However, task complexity likely moderates this relationship: the more complex the task, the less impact self-efficacy has on performance (Stajkovic and Luthans 1998).

Self-efficacy also shows a consistent relationship with the pursuit of entrepreneurship and entrepreneurial success (Rauch and Frese 2007). Two studies in the academic entrepreneurship literature address topics best considered in the realm of self-efficacy. First, in 1989 Gurdon and Samsom conducted interviews with 22 university scientists who had founded companies. Their (2010) article reported a follow-up to those initial interviews. Of the initial 22 companies, 6 of the companies had failed, 4 had been purchased or merged, 3 remained private, and 9 had become public companies. This latter group included some that are now very well known (for example, Biogen and Genzyme). When interviewed in 2001, 9 of the 11 successful scientists specifically noted that management expertise was important. Interestingly, in contrast, none of the failed scientists attributed the dissolution of their companies to management failure. An overall conclusion from the interviews was that the founder's self-efficacy and achievement motivation should be included among the inimitable attributes considered part of competitive advantage in the resource-based view of the firm.

One of the popular measures of entrepreneurial self-efficacy (the one used by Prodan \& Drnovsek) was developed by Chen, Greene, and Crick (1998) in a comparison of entrepreneurs to corporate managers. These authors took seriously the normal recommendation that self-efficacy measures should be domain-specific, so asked about the individual's confidence in fulfilling roles common to anyone in business such as conducting market analysis, creating new products, strategic planning, taking calculated risks, and performing financial analysis. The difficulty, of course, is that such domain-specific questions might mean little or nothing to people who are not already engaged in business. A preferable alternative, used in the US PSED (Gartner et al. 2004; Reynolds 2018; Reynolds and Curtin 2009), is a measure of expectancy (Gatewood 2004; Vroom 1964) that can be worded in a way that works with entrepreneurs and non-entrepreneurs alike.

Vroom's (1964) expectancy theory has been used in more than a few studies of entrepreneurial action and persistence (Gatewood et al. 2002; Manolova et al. 2012; Renko, Kroeck, and Bullough 2012). In the entrepreneurship literature, expectancies for business success are higher among nascent entrepreneurs than among a comparison group of non-entrepreneurs and expectancies are positively related to both entrepreneurial intentions and growth intentions. For this reason, and because of expectancy differences between nascent entrepreneurs and non-entrepreneurs in the PSED studies we hypothesize:

H3: Biomedical scientists who are founders of companies will show higher scores on expectancy than will biomedical scientists who are not founders.

\section{Conscientiousness and Resilience}

The personality literature has for several years subscribed to the view that there are five broad behavioral predispositions that can be used to characterize most people (the "Big Five," Costa and McCrae 1985). The five dimensions are Openness to experience, Conscientiousness, Extraversion, Agreeableness, and Neuroticism (arranged in this order as a mnemonic device, OCEAN). At least one study has examined differences in entrepreneurial behavior based on the Big Five (Ciavarella et al. 2004). Extraversion, emotional stability (the positive end of Neuroticism) and agreeableness were found to be unrelated to venture success, but conscientiousness was positively related to venture survival. For this reason, we included conscientiousness among the scales we employed, expecting that:

H4a: Academics who are founders of biomedical companies will show higher levels of conscientiousness than biomedical academics who are non-founders.

The popular literature argues that resilience ought to be a characteristic of a successful entrepreneur. Indeed, the entire notion of "pivoting" within the "lean startup" framework (Blank 2013; Ries 2011) assumes that an entrepreneur is nimble enough to change and resilient enough to manage under changed circumstances. This might well be even more important among academic entrepreneurs than among entrepreneurs outside the academy. There may be a handful of academic entrepreneurs who have had no journal rejection letters, and 
no declinations of grant proposals. But we suspect that their numbers are quite limited. More common is the revision of a rejected manuscript for submission elsewhere, or the resubmission of a grant proposal after dealing with the reservations of reviewers. In short, resilience. To test for this possibility, we included items that measured resilience, defined as an ability to bounce back from adversity (Windle 2011), and propose:

H4b: Biomedical scientists who are founders of companies will show higher levels of resilience than biomedical scientists who are not founders.

\section{Career Reasons}

Beginning with a study by Scheinberg and Macmillan (1988), a set of "career reasons" has also been found to be related to entrepreneurial performance (Birley and Westhead 1994; Carter et al. 2003; Cassar 2007; Kolvereid 1996; Shaver, Blair, and Davis 2014). Rather than originating from a particular psychological theory, the career reasons were empirically developed, beginning with Scheinberg and MacMillan's (1988) survey of over 1400 business owner/founders in 11 countries. Responses were obtained to 38 items that fell into six broad factors: need for approval, instrumentality of wealth, "communitarianism," and needs for personal development, independence, and escape. These career reasons have been used and modified over the years since their introduction in 1988, with some of the items eliminated while others have been added. Eighteen of the items were included in PSED I, with the 558 responses analyzed by Carter et al. (2003). These investigators identified six factors (in decreasing order of variance accounted for): self-realization, financial success, roles, innovation, recognition, and independence. Only 14 of the 18 were included in PSED II, and when the two datasets were combined, Davis \& Shaver (2009), found three factors: personal reasons such as "to be respected by my friends," financial reasons such as "earn a large personal income," and independence reasons such as "considerable freedom to adapt my approach to work." Recognizing that academic scientists - whether they are founders of companies or not - have substantial freedom of action in their occupations, we shall restrict our discussion to only the first two sets of reasons. Specifically, we propose:

H5: Academic scientists who are founders of biomedical companies should have higher scores on both sets of career reasons than are seen among non-founders.

\section{Commercialization of Biomedical Science}

Perhaps the most important task for this research is to identify the motives that drive biomedical scientists to start companies. There is a place to begin. For example, Lam (2011) conducted both in-person interviews with 36 academics and a Web-based survey of 734 UK scientists based in five different universities. The objective was to determine whether individual commercial interests were more aptly characterized as driven by financial interests ("gold"), reputation and career advancement ("ribbon"), or intrinsic satisfaction ("puzzle"). The research was couched in terms of Self-Determination Theory (SDT, Deci, Olafsen, and Ryan 2017). This theory began as a model of intrinsic versus extrinsic motivation (Deci and Ryan 1980) with the general principle that whether a reward would be positively or negatively motivating would depend on whether the reward was seen as an attempt at external control over the person's actions. It should probably be noted that Deci and Ryan's view of intrinsic motivation is not without its critics (e.g., Lepper, Henderlong, and Gingras 1999). The more recent version of SDT identifies three processes by which external regulations become internalized, reminiscent of the way that Kelman (1961) once described three processes of attitude change. The results showed, among other things, that the most highly endorsed motive for collaboration was to increase the funding for science while the least endorsed motive was to "increase your personal income." This article speaks well to why an academic scientist might seek to engage in commercial activity of some sort (as $73 \%$ of the respondents said they had done). But it does not speak to what we would describe as academic entrepreneurship, because only $10 \%$ of the respondents had actually founded companies.

The motives identified by Lam are similar to the career reasons, but the latter have been studied in only in very broad-based contexts. From Scheinberg and Macmillan (1988) original study to the PSED studies, the respondents have represented founders "in general." For example, the PSED studies, by being nationally representative, have many more retail businesses than high technology businesses, let alone biomedical start-up companies. Consequently, we believed it to be important to create a disciplinary-specific set of reasons either to commercialize or not to do so. The final two sets of questions included in the research were developed on the basis of pilot research conducted in a regional academic medical center that also provided data for the current study. This academic medical center had recently revised its strategic plan, expecting to build its future on 
four "pillars," one of which was Entrepreneurship. To that end, it established an innovation and entrepreneurship center responsible for general improvements in the entrepreneurial ecosystem and for targeted outreach to technology collaborators, private companies, angel investors, and venture capital firms. The pilot research involved semi-structured interviews conducted by one or the other of the authors (most frequently, both sat in on the interview). With approval of the Institutional Review Boards of the authors' home institution and that of the academic medical center, and with the permission of the interviewee, interviews were recorded so that potentially important nuances would not be lost. No interviewees declined to have the sessions recorded.

Interviews began with faculty members known personally by one of us, and continued in snowball fashion with medical entrepreneurs suggested by the initial interviewees. All interviews were conducted at a time convenient to the participants, in the campus office of each participant. To keep the contact in the form of a conversation among professional equals, participants were not asked to sign written consent forms (with the approval of the IRBs of both institutions). After a brief description of the study and its aims, participants were asked a series of questions that captured the essentials of their academic backgrounds and allowed them to express their opinions about the reasons that an academic entrepreneur might, or might not, elect to commercialize a technology originating from his or her laboratory. We reported on the results of these interviews [reference omitted intentionally] and then turned the responses into questions about (a) the perceived positive outcomes of commercialization and (b) the perceived negative outcomes of commercialization. In Table 2 these are, respectively, "rewards" and "impediments." The positive reasons to commercialize included such things as personal satisfaction, the good of society, the possibility of enhanced funding support or reputation, potential for personal income, and added value to the university. The impediments included such things as the sheer effort involved, the time it would take away from pursuing grant funding and publication, the possibility of conflict of interest, and risk to one's academic job. Because they will have actually created new companies, we propose that

H6: Founders of biomedical companies will have higher scores on the positive reasons to commercialize, and lower scores on the reasons not to commercialize, than non-founders.

\section{Methods}

\section{Question Development}

Three different processes were used to develop questions for the present research. First, we relied on a number of items from the PSED. Second, we adapted items from a variety of scales that are useful in examining entrepreneurial behavior (Cassidy and Lynn 1989; Robinson et al. 1991; Shannahan, Bush, and Shannahan 2013; Windle 2011). Third, as just noted, we created closed-ended questions based on in-depth pilot interviews previously conducted in the specific academic setting. The scales included are summarized in Table 1 arranged in the order of the hypothesis tests.

Table 1: Elements of dependent variables, showing the source of items.

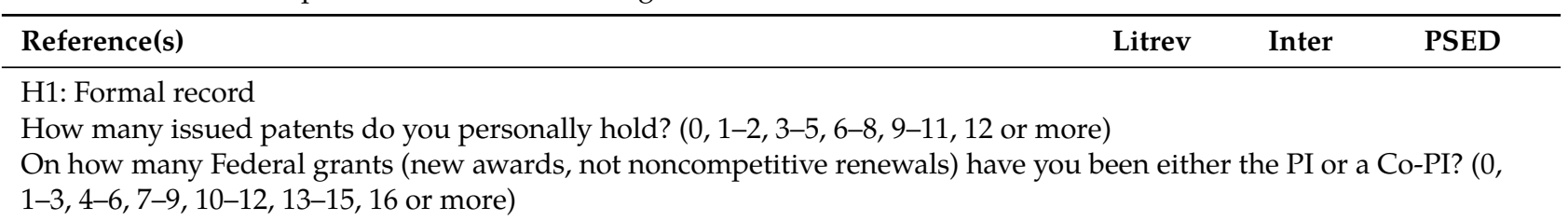

H2a: TPB norms (alpha $=0.64$ )

My institution provides good support for those who start new firms.

Most of the leaders in my scientific community are people who have also started businesses.

Many of my colleagues have started businesses.

CRG

Our technology transfer office goes out of its way to help new businesses start. CRG

H2b: TPB personal control (alpha $=0.79)$

I can do anything I set my mind on doing.

I do every job as thoroughly as possible.

When I make plans, I am almost certain to make them work.

When I get what I want, it is usually because I worked hard for it.

I am typically successful in completing new tasks.

I always reach goals I set for myself. 
H2c: TPB attitude (alpha $=0.46)$

Starting a business would help advance my academic career.

I like to be admired for my achievements.

H3: Expectancy (alpha $=0.62)$

My past experience would be very valuable in starting a business.

Starting a business would help me achieve other important goals in my life.

My skills and abilities would help me start a business.

G

G

G

I believe it is important to analyze your own weaknesses in professional matters.

I spend a considerable amount of time making any organization I belong to better.

I never put important matters off until a more convenient time.

There is satisfaction in a job well done.

To be successful, it is important to use your time wisely.

H4b: Resilience (alpha $=0.73$ )

I am able to overcome obstacles when they appear.

Where most people see problems, I try to look for opportunities.

I can bounce back from any adversity.

I can keep my head when others around me are losing theirs.

H5: Personal and social career reasons (alpha $=0.77$ and 0.67 , respectively)

To have considerable freedom to adapt my own approach to work.

To give myself, my spouse, and my children financial security.

To have greater flexibility for my personal and family life.

To earn a larger personal income.

To have the power to influence an organization.

To follow the example of a person I admire.

To be respected by my friends.

To develop an idea for a product.

To continue a family tradition.

$\mathrm{CL}=$ Cassidy and Lynn (1989)

CRG = Carter, Reynolds, and Gartner (2004)

RS = Robinson et al. (1991)

$\mathrm{W}=$ Windle (2011)

Inter $=$ Developed from interviews

PSED = taken from the Panel Study of Entrepreneurial Dynamics

The PSED. In the United States, the PSED (both PSED I and PSED II) are the only datasets (out of the 57 listed by the US Small Business Administration) that contain any significant detail about the founders of new ventures. Some of the others identify general demographic characteristics of the founder, but none includes information about the founder's background, experience, and personal motivations. Not surprisingly, the US PSED has served as the model for numerous others, including those in Australia, Canada, China, Czech Republic, Denmark, Finland, Germany, Netherlands, Spain, Switzerland, Sweden, and the United Kingdom. Over 125 journal publications (not including chapters, books, or PSED-like studies from other countries) have been based on the PSED studies (Frid 2018). Each US PSED is both wide (over 6,000 variables for PSED I and over 8,000 variables for PSED II) and long (Ns = 1,261 and 1,214, respectively), with a sizable array of questions asked of respondents who were then followed for as much as four years (PSED I) or six years (PSED II). The longitudinal design allows researchers to identify the characteristics of start-up efforts that have (and have not) succeeded. These outcomes appear in a "harmonized" dataset created by Reynolds and described by Reynolds and Curtin (2011). Codebooks and interview schedules for both datasets are publicly available from the Institute of Social Research (ISR) at the University of Michigan http:/ / www.psed.isr.umich.edu/psed/home.

The research included a variety of "person variables" that could be used to predict entrepreneurial success as well as a set of start-up activities that provide a fine-grained description of the progress made toward organizing the business. The person variables included measures of achievement motivation, expectancies, locus of control, risk aversion, and the 18 career reasons (14 in PSED II). There were 25 start-up activities, including such things as investigating the potential of a market, writing a business plan, seeking external funding, renting space or a location, engaging various business support professionals, and hiring employees. Conceptual variables in the present study that involve PSED-based items are indicated by asterisks in the last column of Table 1. 
TPB items. Some of the items relevant to TPB norms, personal control, and attitude are derived from the PSED. Others were taken from prior scales created by Robinson et al. (1991), Cassidy and Lynn (1989) and described by Carter, Reynolds, and Gartner (2004) and a few from our early interviews. The TPB items assessing norms are obviously quite close to the notion of "reference groups" advanced in some of the earlier research on academic entrepreneurship (e.g., Kalar and Antoncic 2015). In addition to the items related to social norms supporting entrepreneurship, Table 1 shows the items used to assess felt personal control (which are also relevant for achievement) and positive attitudes toward commercialization. Cronbach's alpha values are reported for each subscale of the TPB.

Expectancy. As noted above, it is awkward at best to present items about specific business activities (as in the scale of entrepreneurial self-efficacy, by Chen, Greene, and Crick 1998) to academic scientists who have no intention whatsoever of going into business. For this reason, we elected to ask items about potential business successes (expectancies) drawn from the PSED (Gatewood 2004).

Conscientiousness and resilience. Items used to assess conscientiousness were adapted from elements of scales described by Cassidy and Lynn (1989), by Robinson et al. (1991) and from the PSED. In a detailed conceptual analysis of resilience, Windle (2011) considered its environmental, personal, and process features. One common feature was a person's ability to "bounce back" from some form of setback, leading us to create an item "I can bounce back from any adversity." Another common feature is the possession of personal resources sufficient to deal with stress, which we represented with a PSED item, "I am able to overcome obstacles when they appear."

Career reasons. We used a shortened list of the career reasons. In an analysis of data from both PSED I and PSED II, Shaver, Blair, and Davis (2014) showed that the 14 career reasons common to both versions of the PSED could best be represented as two dimensions - reasons having to do with personal gain and reasons having to do with making a social difference.

Biomedical commercialization. Although we expected that variables that make a difference in non-academic entrepreneurship would carry over to the academic context, we also believed it critically important to develop items that were specific to biomedical commercialization. Policies established by many federal agencies that support biomedical research strongly encourage not only the disclosure (to the university administration or TTO) of research products that might be patentable, but the reporting of outcomes of any clinical trial. Indeed, recent definitions of "clinical trial" proposed by the National Institutes of Health are sufficiently broad and unforgiving that they have raised the ire of more than a few scientific societies (Kaiser 2017, accessed January 3 , 2019). Because of the institutional pressures to report inventions and file preliminary patents, those activities may be less predictive of company-formation than one might think. Consequently, the commercialization items from our pilot research may be a valuable supplement to the other measures. The items for facilitating factors and impediments are included in detail in Table 2.

Table 2: University-based reasons to commercialize or not to do so.

Positive reasons to commercialize

It helps individuals who can benefit from the device or drug.

It is personally rewarding to see an idea get to market.

It contributes to promotion and/or tenure at the institution.

It can be a source of personal income for the scientist.

It can create a revenue stream for the university.

It is good for society.

It increases the scientist's chances of obtaining grant support in the future.

It is another source of support for the scientist's laboratory.

It is likely to gain respect from others.

Impediments to commercialization

Publications are more important than commercialization.

Most scientists are uncomfortable promoting/managing a business.

The commercialization process takes too much effort away from other things.

Business interests could compromise the scientist's objectivity.

Negotiating time off might threaten the scientist's job at the university.

Money is scarce at the university, so individuals should focus on getting grants.

It is too expensive for the university.

It doesn't contribute to promotion and tenure.

It is more lucrative to leave the university to pursue the idea. 


\section{Procedure}

The scales described in Table 1 and the university-based reasons to (or not to) commercialize shown in Table 2 were entered into an online third-party survey platform along with 8 other items that were subsequently dropped to bring Cronbach's reliability estimates as high as they could be. Additionally, respondents were asked about their academic and professional histories. Respondents were invited to take the survey in an email that originated from the office of the Associate Provost for Research. In part, the invitation read,

It is no secret that academic medical centers are interested in the commercialization of products and processes discovered in their laboratories. Federal granting agencies are increasingly interested in commercialization, standards for promotion and tenure are beginning to recognize the importance of commercialization, individual academic medical scientists want their discoveries to have benefits for patients. This research uses a combination of questions from (a) nationally-representative entrepreneurship research, (b) established measures of entrepreneurial intentions, and (c) items specifically developed on the basis of prior work at [the institution] to try to capture the reasons that academic medical scientists might - or might not - choose to commercialize their findings.

Respondents were informed that the research had been approved by the IRBs at both institutions, that the data would be anonymous (no DNS numbers were captured and respondents were explicitly told not to include any information that might identify them).

\section{Participants}

The message was sent to the widest list possible - which turned out to be 1,056 research principal investigators. In hopes of enhancing the response rate, a second message was sent out a week later that used the previous week's heavy rain and flooding as the rationale for the second contact. But even with two messages, only 55 responses were received (a shade over $5 \%$ of the original list). Of these, 5 individuals answered only the commercialization questions, leaving all of the opinion items blank. Thus, the final sample of usable responses was 50 people, a total small enough that any differences must be quite substantial to reach statistical significance. Among these 50 individuals, there were 16 females and 34 males; 44 with terminal degrees at the doctoral level (MD, PhD, DDS), 6 without such degrees; 21 with research appointments, 9 with clinical appointments, 15 with clinical/research appointments, and 5 with other forms of appointment. In all of these areas, the sample is representative of the research staff of the institution.

\section{Results}

Initial analyses. The original plan was to test the scales with factor analyses and then employ structural equation modeling to determine which elements contributed the most to faculty commercialization decisions (both licensing and creating companies). Needless to say, with more items than respondents, neither of these alternatives was available. As a result, we could only (a) test each one for internal consistency with Cronbach's reliabilities (SPSS v. 24, for each whole scale and the same scale with each item removed), (b) test for correlations among the dependent variables with Pearson correlations, and (c) use a Bonferroni correction of the alpha level where there were cross-dependent-variable correlations. Cronbach's reliabilities are shown in Table 1 for the elements of the TPB (norms, 0.64; personal control, 0.79; attitude, 0.46); expectancy (0.62), conscientiousness (0.72), resilience (0.73); personal career reasons $(0.77)$, and social career reasons $(0.67)$. We would have preferred for all of these to be higher, as their marginal values (Nunnally 1978) reduce our likelihood of finding significant differences. As for the correlations among dependent variables, the patent dependent variable was negatively correlated $(r=-0.38, p<0.05)$ with the TPB personal control element, but showed no correlation with any other dependent variable. Correlations among the psychological variables (three elements of the TPB; and expectancy, conscientiousness, and resilience) are shown in Table 3.

Table 3: Correlations among psychological dependent variables.

\begin{tabular}{lllllll}
\hline Dependent variable & $\mathbf{1}$ & $\mathbf{2}$ & $\mathbf{3}$ & $\mathbf{4}$ & $\mathbf{5}$ & $\mathbf{6}$ \\
\hline TPB norms (1) & & -0.19 & 0.27 & 0.08 & -0.02 & 0.10
\end{tabular}




$\begin{array}{lllll}\text { TPB personal control } & 0.09 & 0.47^{* *} & 0.62^{* *} & 0.66^{*} \\ \text { (2) } & & & & 0.16 \\ \text { TPB attitude (3) } & & & 0.01 & 0.14 \\ \text { Expectancy (4) } & & & & 0.44^{*} \\ \text { Conscientiousness } & & & 0.71^{* *}\end{array}$

(5)

Resilience (6)

$1 * p<.05$, two-tailed. ${ }^{* *} p<.01$, two-tailed.

The personal career reasons and the social career reasons are omitted from this table because only one of the 14 possible correlations was significant (social reasons and conscientiousness, $r=0.35, p<0.05$ ). Because of the relationships among TPB elements (tested in H3), expectancy (tested in H4), and conscientiousness and resilience (tested in $\mathrm{H} 5 \mathrm{a}$ and b) we used a Bonferroni correction for these three hypotheses, thus reducing the alpha level to 0.017 . All other hypotheses will be tested with alpha $=0.05$.

Grouping variable. The original objective of the research was to compare the responses of individuals who had either licensed a technology originating from their laboratories or who had actually created companies (or both). With the general caveat that the final sample is small, it is interesting to note that there were 11 respondents out of the 50 who had created companies. Disappointingly, however, only 1 of the 11 companies created was started by a woman (against a US average of $11 \%$ among women across all business sectors). We fear that this result puts us in good company in the literature on academic entrepreneurship (e.g., Bercovitz and Feldman 2008; Mosey and Wright 2007; Prodan and Drnovsek 2010), but with over a third of bioengineering doctorates in the US now earned by women (http://www.nsf.gov/statistics/sed/2013/data-tables.cfm), we hope that it will change in the future. Rather than use the various scales as a set of independent variables to predict business start/nonstart, we elected to use whether the respondent reported a company or not as a grouping variable in a series of analyses of variance. ${ }^{1}$ To minimize experimentwise error, we have tested the scales in repeated-measures ANOVAS where combining the various dependent variables made conceptual sense.

Formal activity. As previously noted, in the literature that examines the effectiveness of university TTOs, patent activity is often a primary measure of the university's commercial activity (Geuna and Rossi 2011; Link, Siegel, and Van Fleet 2011). Patents, together with numbers of inventions disclosed (e.g., Thursby and Thursby 2011a, 2011b), numbers of spin-off companies created (Di Gregorio and Shane 2003; Fini et al. 2011; Kenney and Patton 2011), numbers of incubator tenants (e.g., Clarysse et al. 2005), and even numbers of faculty members who participate on scientific boards of private companies (Stuart and Ding 2006) certainly indicate the extent to which a university participates in business activities.

Our first hypothesis was that founders would possess more issued patents than would non-founders. We asked respondents to indicate how many issued patents they personally held, on a 6-point category scale with $1=$ zero and $6=12$ or more. We also asked respondents to indicate how many federal grants they had held during their careers (new awards, not non-competing renewals). The scale we used categorized the answers into a 7-point scale with $1=$ zero, categories 2 through 6 each representing 3 grants, and category 7 representing 16 or more. Mean scores and standard deviations for these two category variables are shown in Table 4 . The two were tested in a $2 \times 2$ (company/not $X$ variable) repeated measures analysis of variance. Even with the small sample size, the results were statistically significant, confirming H1. The main effect for the grouping variable showed that respondents who had started companies had both more federal grants and more patents than respondents who had not done so, $F(1,48)=6.48, p<0.015$, partial eta squared $=0.47 .^{2}$ The main effect for the difference between grants and patents was also significant, but is not meaningful because of the differences in category width.

Table 4: Grant and patent histories for founders and non-founders.

\begin{tabular}{llll}
\hline & $\begin{array}{l}\text { Founders } \\
\boldsymbol{n = 1 1}\end{array}$ & $\begin{array}{l}\text { Non-founders } \\
\boldsymbol{n}=\mathbf{3 9}\end{array}$ & $\begin{array}{l}\text { Total } \\
\boldsymbol{n}=\mathbf{5 0}\end{array}$ \\
\hline $\begin{array}{l}\text { Federal grants obtained } \\
\text { (category) }\end{array}$ & & \\
$M$ & & & 3.66 \\
$S D$ & 4.55 & 3.41 & \\
Patents personally held & 2.25 & 2.07 & \\
(category) & & & 1.48 \\
$M$ & & & \\
$S D$ & 2.27 & 1.26 & \\
\hline
\end{tabular}


Theory of planned behavior. Not only because starting a company is a planned behavior that extends through time, but also because the TPB has previously been used in studies of academic entrepreneurship (e.g., Goethner et al. 2012), our second hypothesis was that scores on the various elements of the TPB would be higher for biomedical scientists who had started companies than for biomedical scientists who were not company founders. Mean scores for this hypothesis appear in Table 5 and were tested by a $2 \times 3$ ANOVA (founder/not X norms-personal control-attitude) with repeated measures on the second factor. There was only one significant effect obtained in this analysis: regardless of founding status, scores for personal control were higher than scores for either norms or attitude, $F(1,45)=163.74$ for the quadratic component, $p<0.000$ (well under the Bonferroni-corrected alpha level), partial eta squared $=0.78$. Thus, Hypothesis 2 was not confirmed.

Table 5: Elements of the TPB by founders and non-founders.

\begin{tabular}{llll}
\hline & $\begin{array}{l}\text { Founders } \\
\boldsymbol{n = 1 1}\end{array}$ & $\begin{array}{l}\text { Non-founders } \\
\boldsymbol{n}=\mathbf{3 6}\end{array}$ & $\begin{array}{l}\text { Total } \\
\boldsymbol{n}=\mathbf{4 7}\end{array}$ \\
\hline Norms & & & \\
$M$ & 2.15 & 2.11 & \\
$S D$ & 0.77 & 0.64 & \\
& & & 3.80 \\
Personal control & & & \\
$M$ & 3.80 & 3.81 & \\
$S D$ & 0.61 & 0.52 & 2.05 \\
Attitude & & & \\
$M$ & & & \\
$S D$ & 1.95 & 2.08 & \\
\hline
\end{tabular}

Self-efficacy and expectancy. As noted earlier, the "standard" tests of entrepreneurial self-efficacy (such as Chen, Greene, and Crick 1998) contain questions about business activities that really make no sense for people who do not have companies. Our substitute was expectancy, which has been used in more than a few studies of entrepreneurial action and persistence (Gatewood et al. 2002; Manolova et al. 2012; Renko, Kroeck, and Bullough 2012). Our H3 was that as a proxy for self-efficacy, expectancy scores would be higher for founders than for biomedical scientists who were not founders of companies. This hypothesis was not confirmed, as the difference between founders $(M=3.15, S D=0.67)$ and non-founders $(M=2.71, S D=0.88)$ was not significant, $F(1$, 49) $=2.26$, n.s.

Conscientiousness and resilience. Because of the finding in the non-academic context that conscientiousness was related to venture survival (Ciavarella et al. 2004), our H4a was that founders would have higher scores than non-founders. Next, the popular literature argues that resilience ought to be a characteristic of a successful entrepreneur. Consequently, our H4b predicted that founders would show higher levels of resilience compared to non-founders. The results for both conscientiousness and resilience are shown in Table 6. Again, we conducted a $2 \times 2$ (founder/not $X$ trait) analysis of variance with repeated measures on the second factor. The only significant effect (Bonferroni corrected) in this analysis was a main effect for trait, with scores for all respondents higher on conscientiousness than on resilience, regardless of founding status, $F(1,48)=13.70$, $p<0.001$, partial eta squared $=0.22$. Thus, neither $\mathrm{H} 4 \mathrm{a}$ nor $\mathrm{H} 4 \mathrm{~b}$ was confirmed.

Table 6: Scores for conscientiousness and resilience by founders and non-founders.

\begin{tabular}{llll}
\hline & $\begin{array}{l}\text { Founders } \\
\boldsymbol{n = 1 1}\end{array}$ & $\begin{array}{l}\text { Non-founders } \\
\boldsymbol{n = 3 9}\end{array}$ & $\begin{array}{l}\text { Total } \\
\boldsymbol{n}=\mathbf{5 0}\end{array}$ \\
\hline Conscientiousness (6 items) & & & \\
$M$ & 4.11 & 3.88 & 3.93 \\
$S D$ & 0.33 & 0.67 & \\
Resilience (3 items) & & & \\
$M$ & 3.79 & 3.57 & 3.62 \\
$S D$ & 0.60 & 0.67 & \\
\hline
\end{tabular}

Career reasons. As noted earlier, the set of "career reasons" has also been found to be related to entrepreneurial performance (Birley and Westhead 1994; Carter et al. 2003; Cassar 2007; Kolvereid 1996; Shaver, Blair, and Davis 2014). Consequently, our H5 stated that company founders should have higher scores on both personal and so- 
cial reasons than would biomedical scientists who were not founders of companies. This hypothesis was tested in a $2 \times 2$ (founder $/$ not $X$ reason) analysis of variance with repeated measures on the second factor. The results are shown in Table 7. Again, there were no significant differences between founders and non-founders. The only significant result was that, regardless of founding status, scores were higher on the personal career reasons than on the social career reasons, $F(1,48)=28.40, p<0.000$ (again quite significant despite the Bonferroni correction), partial eta squared $=0.37$. Thus, Hypothesis 5 was not confirmed.

Table 7: Scores for personal and social career reasons by founders and non-founders.

\begin{tabular}{llll}
\hline & $\begin{array}{l}\text { Founders } \\
\boldsymbol{n = 1 1}\end{array}$ & $\begin{array}{l}\text { Non-founders } \\
\boldsymbol{n}=\mathbf{3 9}\end{array}$ & $\begin{array}{l}\text { Total } \\
\boldsymbol{n}=\mathbf{5 0}\end{array}$ \\
\hline Personal reasons & & & \\
$M$ & 3.18 & 3.47 & \\
$S D$ & 0.98 & 0.80 & \\
Social reasons & & & 2.41 \\
$M$ & 2.33 & 2.42 & \\
$S D$ & 0.90 & 0.79 & \\
\hline
\end{tabular}

Specific reasons to (or not to) commercialize. In keeping with the reference-group view of academic entrepreneurship (Bercovitz and Feldman 2008; Tartari, Perkmann, and Salter (2014)), we attempted to identify characteristics of the local setting that would either encourage or discourage people from creating companies. Our H6 specified that founders of companies would have generally more favorable views of the objectives that could be accomplished by creating a new business, and would also have less concern about local organizational factors that might add to the difficulty of commercialization. As we had done with the various psychological measures, we first conducted Pearson correlations among the facilitating factors, then a second set of Pearson correlations among the impediments. Results of these correlations are shown in Table 8 and Table 9. It is apparent from the patterns of correlations that whether the topic was the perceived factors that facilitate commercialization or the perceived impediments to commercialization, the items fell into two distinct clusters. (NOTE: In both tables only the significant correlations are shown, to clarify the interpretation.)

Table 8: Significant correlations among factors perceived to facilitate commercialization.

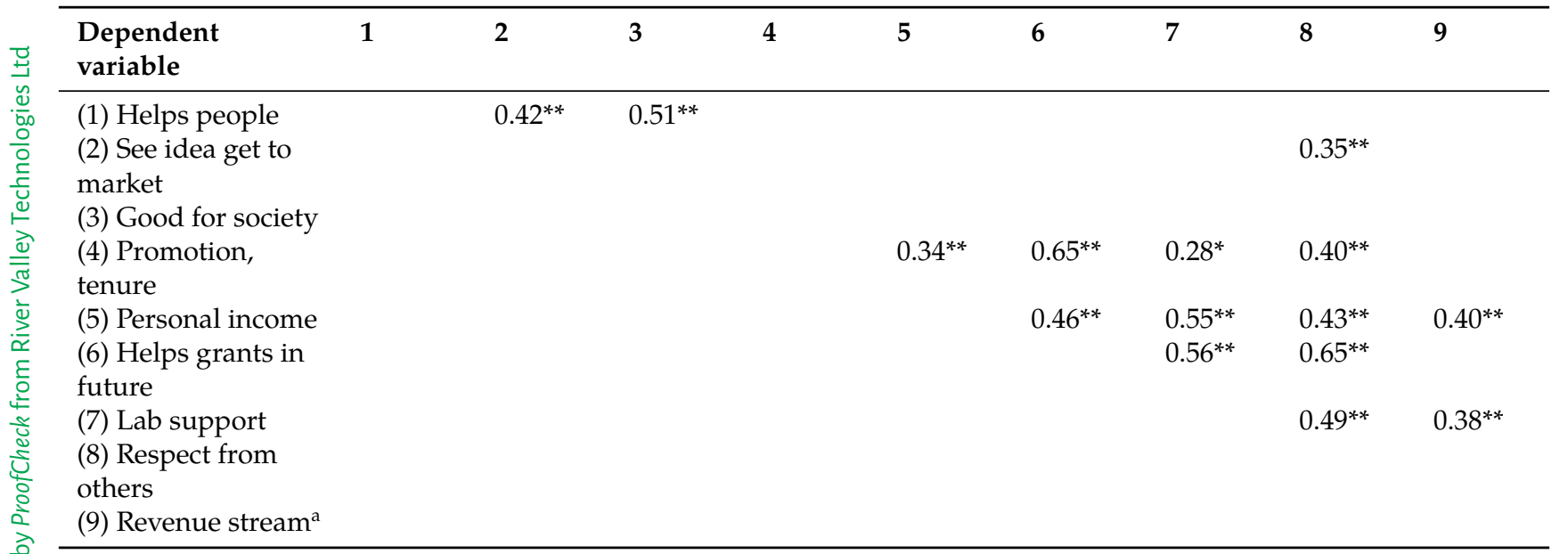

aBecause "revenue stream" showed no significant correlations and its inclusion reduced the Cronbach's alpha for the subscale, it was dropped from the analysis.

Table 9: Significant correlations among factors perceived to impede commercialization.

\begin{tabular}{|c|c|c|c|c|c|c|c|c|c|}
\hline $\begin{array}{l}\text { Dependent } \\
\text { variable }\end{array}$ & 1 & 2 & 3 & 4 & 5 & 6 & 7 & 8 & 9 \\
\hline $\begin{array}{l}\text { (1) Pubs more } \\
\text { important }\end{array}$ & 1 & $0.52^{* *}$ & $0.44^{* *}$ & $0.43^{* *}$ & & & & $0.26^{*}$ & $0.27^{*}$ \\
\hline
\end{tabular}


(2) Discomfort at business

(3) Too much effort

(4) Compromise

objectivity

(5) Threaten job

(6) Money scarce

(7) Too expensive

(8) No help with

promotion

(9) More lucrative

to leave
$1 \quad 0.34^{*} \quad 0.35^{* *}$

1

$0.29^{*}$

1

1

$0.38^{* *}$
1

$0.33^{*}$
$0.48^{* *}$

$0.61^{* *}$

$0.47^{* *}$

$0.46^{* *}$

$0.41^{* *}$

$0.46^{* *}$

0.51

$1 \quad 0.35^{* *}$

${ }^{1}$ In both Tables 8 and $9,{ }^{*}$ designates $p<.05$ whereas ${ }^{* *}$ designates $p<.01$, both two-tailed.

These two tables of correlations make it clear that rather than treat all perceived facilitating factors as a single scale, the items should be separated into two subscales, one dealing with societal benefit (helps others, rewarding to see an idea come to fruition, good for society; Cronbach's alpha $=0.61$ ) and one dealing with financial and reputational benefits for the scientist (promotion and tenure, personal income, improves future grant possibilities, supports the lab, increases respect, and provides a revenue stream for the university). As shown in Table 8 , this last element - university revenue stream - was not significantly correlated with any of the other facilitative factors. Cronbach's reliability for the financial and reputational subscale was improved (to alpha $=0.82$ ) when it was dropped. Although the "good for society" element was also not significantly correlated with other elements, dropping it from the societal benefit subscale reduced the Cronbach's reliability, so the element was retained.

Turning to the perceived impediments to commercialization, the correlations show a comparable split into two subscales, one dealing with the role of the scientist (publications, discomfort at business management, expenditure of effort that detracts from other things, and potential compromising of scientific objectivity; Cronbach's alpha $=0.72$ ) and one dealing with institutional issues (potential threat to one's job, general scarcity of money, expense involved in commercialization, no help with promotion and tenure, and the view that it would be more lucrative to commercialize outside the university; Cronbach's alpha $=0.80$ ).

Given these splits in both lists of factors perceived to affect commercialization, it made sense to do two separate tests of $\mathrm{H} 6$, one for the perceived facilitators and one for the perceived impediments. Consequently, we performed two $2 \times 2$ repeated measures analyses of variance on the scores shown in Table 10 .

Table 10: Means for perceived facilitators of, and impediments to, commercialization.

\begin{tabular}{|c|c|c|c|}
\hline & $\begin{array}{l}\text { Founders } \\
n=\mathbf{1 1}\end{array}$ & $\begin{array}{l}\text { Non-founders } \\
n=38\end{array}$ & $\begin{array}{l}\text { Total } \\
n=49\end{array}$ \\
\hline \multicolumn{4}{|c|}{ Perceived facilitative forces toward commercialization } \\
\hline \multicolumn{4}{|c|}{ Societal benefit } \\
\hline M & 4.31 & 4.09 & 4.14 \\
\hline$S D$ & 0.98 & 0.87 & \\
\hline \multicolumn{4}{|c|}{ Reputational/financial benefit } \\
\hline$M$ & 2.67 & 3.56 & 3.36 \\
\hline$S D$ & 0.61 & 0.52 & \\
\hline \multirow{2}{*}{\multicolumn{4}{|c|}{$\begin{array}{l}\text { Perceived impediments to commercialization } \\
\text { Scientist role }\end{array}$}} \\
\hline & & & \\
\hline M & 2.95 & 3.27 & 3.20 \\
\hline$S D$ & 0.88 & 0.81 & \\
\hline \multicolumn{4}{|c|}{ Institutional pressures } \\
\hline$M$ & 2.85 & 2.84 & 2.85 \\
\hline$S D$ & 0.99 & 0.96 & \\
\hline
\end{tabular}

The first was (founder/not $X$ nature of the benefit) with repeated measures on the second factor. The second was (founder/not $X$ nature of the impediment), also with repeated measures on the second factor. Analysis of the facilitating forces showed a significant interaction between the grouping variable and the repeated measure, $F(1,47)=11.97, p<0.001$, partial eta squared $=0.20$, such that founders had higher scores on societal benefit but lower scores on financial and reputational benefits. Interestingly, the ANOVA on perceived imped- 
iments showed no such difference, indeed, no significant differences whatsoever. Taken together these results are an important confirmation of the idea initially represented in H6, which predicted that founders would have more positive scores on the factors presumed to facilitate commercialization. But the results mean more than that: founders are specifically responding to the societal benefits inherent in biomedical commercialization, eschewing both reputational and financial implications. It is important to note that respondents were not asked why they, personally, elected to create companies (or not), so it is unlikely that these results are merely self-presentation.

\section{Discussion}

Lessons learned. We began this research with the expectation- in the absence of research to the contrary - that the overall motivational patterns of academic medical scientists who founded companies would be similar to the patterns seen in founders of other companies. There is a large literature showing aspects of the TPB strongly related to entrepreneurial intentions (e.g., Krueger Jr 2017; Lortie and Castogiovanni 2015; Miranda, Chamorro, \& Rubio 2017; Schjoedt 2018). The same is true for self-efficacy and other psychological characteristics such as elements of the Big Five (e.g., Hsu, Wiklund, and Cotton 2017; Newman et al. 2019; Obschonka and Stuetzer 2017). And in a large number of internationally-based studies, the career reasons have also been consistently predictive of entrepreneurial behavior (e.g., Carter et al. 2003; Cassar 2007; Shaver, Blair, and Davis 2014). Fortunately, we did not stop with "what works elsewhere," but also developed a series of measures specific to the context of academic medical science.

On the general theory that past behavior might be a good predictor of present behavior, we began by examining the patenting and grant histories of our respondents. Our first hypothesis was that the academic scientists who were founders of biomedical companies would have more extensive histories of issued patents. That hypothesis was confirmed and there was a comparable difference between founders and non-founders in the number of new competitive research grants obtained. It is important to note that these differences were obtained in an overall institutional setting where invention disclosure is strongly mandated by federal granting agencies and where maintaining continuous grant support is a clear organizational imperative. Indeed, most of the faculty at the institution are expected to raise a large fraction of their academic salaries as well as to provide external funding for their labs, students, and postdoctoral fellows. Even in this institutional context, the patenting behavior of founders stands apart from that of their colleagues.

Interestingly, the same cannot be said for the various psychological motivations drawn from entrepreneurship research at large. Where the TPB was concerned, there were no differences between founders and nonfounders on the importance of social norms, beliefs in personal control, or attitudes toward business, thus failing to confirm Hypothesis 2. True, the internal consistency of the norms variable was borderline, and the internal consistency of the attitude variable was quite low. Yet the analysis still showed significantly higher scores for personal control than for norms or attitudes, suggesting that the lack of support for H2 was not merely a statistical aberration. After the fact, of course, it is convenient to note that accomplished academic biomedical scientists - whether they are company founders or not - are thoroughly inculcated with the norms of their chosen disciplines and have personal histories of great achievement enabled by restricting their focus to what will most effectively advance their careers.

Not only were there no differences between founders and non-founders on elements of the TPB, that lack of differences continued for the other three psychological principles tested in Hypotheses 3 and 4 . The results for expectancy (H3) were in the predicted direction, with scores for founders being higher than those for nonfounders, but the difference was not significant. For conscientiousness and resilience (H4) the outcome was the same, with no differences between founders and non-founders, but with scores for conscientiousness being significantly higher than those for resilience. Again, after the fact it is easy to attribute the results to self-selection within the profession. For a biomedical scientist, conscientiousness is essential for continued success, and with the current high rates at which even very strong grant proposals are declined, a certain level of resilience goes with the territory.

Turning to the career reasons, once more (H5) there were no differences between founders and nonfounders, though again there was a significant difference between what has been called the "personal motives" and the "social motives," with scores on the former being higher. Here there is further reinforcement of the emerging idea that all academic biomedical scientists are, in an important sense, highly entrepreneurial. They all have "considerable freedom to adapt their own approach to work." They have positions that provide financial security, that allow more flexibility than a typical corporate job, and that provide a good income (assuming consistent grant support!). By contrast, unless they enter academic administration, they have no real desire to "influence an organization," or to "develop an idea for a product." Some may be continuing a family tradition 
or following the example of a person they admire, but these reasons are perhaps less important in academic research than in many other walks of life.

So, what does drive academic biomedical scientists to create companies? The clear answer (H6) is the potential for such companies to make a difference for humanity. Our respondents said, effectively, that biomedical commercialization provides individual health benefits and is good for society as a whole, both of which results the scientists find personally rewarding. This may be an answer to Allen's (2012) question about the intrinsic motives behind scientific and technological commercialization, at least in the biomedical space. Moreover, this set of potential motives was clearly in opposition to the financial and organizational benefits that might accrue from commercial activity.

Implications. There are at least three general conclusions that can be drawn from the overall pattern of results obtained in this study. First, the nature of the occupation matters a great deal. This is not a statement about "industry sector," a variable common to much of entrepreneurship and management research. Rather, it is a statement about the need to examine the everyday working lives of people who are in a position to create companies, because when it comes to assessing entrepreneurial motives, "one size does not fit all." Principles that distinguish entrepreneurs from corporate managers, or differentiate the everyday folks who decide to start companies from the everyday folks who elect not to do so, do not seem to apply in the relatively rarified setting that is an academic medical center. The second general conclusion is that, despite the failure of the traditional motivational principles, there are motives that separate the scientists who are founders of biomedical companies from the scientists who are non-founders. The third general conclusion is that among those motives, it is the value for humanity as a whole that is the driving force. To Lam's motives of "gold, ribbon, and puzzle," we would add "gift," not for the scientist, but for the world.

Limitations and future directions. No single study is either perfect or conclusive, so the easiest way to end a discussion of findings is to point out the need for future research. In this vein, we would make several recommendations. Most importantly, we would hope for a larger sample size in the future, especially for one that includes sufficient women founders of biomedical companies to allow us to answer questions about possible gender differences in overall motivational patterns. A targeted recruitment method that obtains founders using records of the institution's TTO, coupled with a broad announcement to obtain non-founders, would be more likely to produce a sample that would permit a more robust test of our hypotheses. Second, though we have information on how current norms are perceived, we do not have information on the commercialization norms in effect at the institutions where our respondents received their research and postdoctoral training. Because we were already asking the two Institutional Review Boards to approve research that included no written consent form and used employees of the academic medical center, we needed to assure respondents that the data collected would be anonymous, thus precluding any examination of respondent academic history. Third, although we are delighted with the results for H6, we would like to have a stronger link between the motives endorsed in general and the scientists' founding activities. Saying that "because it is good for society" is a reason to commercialize, is not exactly the same as saying that "societal benefit is my reason to commercialize." As noted above, the current wording is probably less likely to raise self-presentational issues, but a more direct wording could be accompanied by a measure of social desirability to add the needed protection.

Conclusion. Even with these limitations, we argue that the results overall lend credence to the claim that it is important to understand the jockeys, as well as the horses. Of most importance is that different from the literature on traditional entrepreneurs, differences between biomedical scientists who have not founded companies and those who have are based less on individual difference factors and more on context-specific motives. Certainly it is true that academic institutions can develop programs and activities that enhance the local ecosystem for commercialization. But even these programs are more likely to have the desired effect if they take into account the motives of the scientists whose work takes place in that ecosystem. What is most exciting and encouraging is that biomedical entrepreneurs - those scientists who have founded companies - appear to have done so in order to help others. Understanding that set of motives should have an important place in the institution's policy and reward structure.

\section{Notes}

1 A reviewer of an earlier version of this manuscript objected to the use of parametric statistics on data scored as a Likert scale. However, we side with Carifio and Perla (2008), who note that "Monte Carlo studies of the F-test have shown the F-test to be extremely robust to violations of its assumptions ..." (p. 1150). Norman (2010) goes even farther to note that if critics "are right and we cannot use parametric methods on Likert scale data, and we have to prove that our data are exactly normally distributed, then we can effectively trash about $75 \%$ of our research on educational, health status and quality of life assessment ..." (p. 627).

2 Respondents did not always answer all of the questions, so the error degrees of freedom are not identical for all statistical tests. 


\section{References}

Acs, Z., P. Braunerhjelm, D. Audretsch, and B. Carlsson. 2009. “The Knowledge Spillover Theory of Entrepreneurship." Small Business Economics 32 (1): 15-30. doi:10.1007/s11187-008-9157-3.

Ajzen, I. 1985. "From Intentions to Actions: A Theory of Planned Behavior." In Action Control: From Cognition to Behavior, edited by ]. Kuhl, and ]. Beckmann, 11-39. Berlin, Germany: Springer-Verlag.

Aldridge, T. T., and D. Audretsch. 2011. “The Bayh-Dole Act and Scientist Entrepreneurship.” Research Policy 40 (8): 1058-67. doi:10.1016/j.respol.2011.04.006.

Allen, K. R. 2012, April. “Technology Commercialization: Have We Learned Anything?” Paper presented at the Gateway Entrepreneurship Research Conference, St Louis, MO.

Audretsch, D. B., A. N. Link, and I. Peña-Legazkue. 2013. “Academic Entrepreneurship and Regional Economic Development: Introduction to the Special Issue." Economic Development Quarterly 27 (1): 3-5. doi:10.1177/0891242412473191.

Banal-Estañol, A., I. Macho-Stadler, and D. Pérez-Castrillo. 2013. "Research Output From University-Industry Collaborative Projects." Economic Development Quarterly 27 (1): 71-81. doi:10.1177/0891242412472535.

Bandura, A. 1977. "Self-Efficacy: Toward a Unifying Theory of Behavioral Change." Psychological Review 84: 191-215.

Bandura, A. 2012. “On the Functional Properties of Perceived Self-Efficacy Revisited." Journal of Management 38 (1): 9-44. doi:10.1177/0149206311410606.

Bercovitz, ]., and M. Feldman. 2008. “Academic Entrepreneurs: Organizational Change at the Individual Level.” Organization Science 19 (1): 69-89.

Birley, S., and P. Westhead. 1994. "A Taxonomy of Business Start-Up Reasons and Their Impact on Firm Growth and Size." Journal of Business Venturing 9 (1): 7-31.

Blank, S. 2013. “Why the Lean Start-Up Changes Everything." Harvard Business Review 91 (5): 63-72.

Boardman, C. P., and B. L. Ponomariov. 2009. “University Researchers Working with Private Companies." Technovation 29 (2): 142-53. doi:10.1016/j.technovation.2008.03.008.

Caiazza, R., S. Shane, and G. Ferrara. 2017. “Guest Editorial." Journal of Management Development 36: 142-45. doi:10.1108/JMD-12-2016-0304.

Carifio, J., and R. Perla. 2008. "Resolving the 50-Year Debate around Using and Misusing Likert Scales." Medical Education 42: 1150-52.

Carter, N. M., W. B. Gartner, K. G. Shaver, and E. J. Gatewood. 2003. “The Career Reasons of Nascent Entrepreneurs." Journal of Business Venturing 18 (1): 13-39.

Carter, N. M., P. D. Reynolds, and W. B. Gartner. 2004. “Perceptions of Entrepreneurial Climate." In Handbook of Entrepreneurial Dynamics: The Process of Business Creation, edited by W.B. Gartner, K.C. Shaver, N.M. Carter, and P.D. Reynolds, 412-20. Thousand Oaks, CA US: Sage Publications.

Cassar, G. 2007. “Money, Money, Money? A Longitudinal Investigation of Entrepreneur Career Reasons, Growth Preferences and Achieved Growth." Entrepreneurship \& Regional Development 19 (1): 89-107. doi:10.1080/08985620601002246.

Cassidy, T., and R. Lynn. 1989. "A Multifactorial Approach to Achievement Motivation: The Development of A Comprehensive Measure." Journal of Occupational Psychology 62 (4): 301-12.

Chang, Y.-C., P. Y. Yang, B. R. Martin, H.-R. Chi, and T.-F. Tsai-Lin. 2016. “Entrepreneurial Universities and Research Ambidexterity: A Multilevel Analysis." Technovation 54: 7-21. doi:10.1016/j.technovation.2016.02.006.

Chen, C. C., P. G. Greene, and A. Crick. 1998. “Does Entrepreneurial Self-Efficacy Distinguish Entrepreneurs from Managers?" Journal of Business Venturing 13: 295-316.

Ciavarella, M. A., A. K. Buchholtz, C. M. Riordan, R. D. Gatewood, and G. S. Stokes. 2004. “The Big Five and Venture Survival: Is There a Linkage?" Journal of Business Venturing 19: 465-83.

Clarysse, B., V. Tartari, and A. Salter. 2011. "The Impact of Entrepreneurial Capacity, Experience and Organizational Support on Academic Entrepreneurship." Research Policy 40 (8): 1084-93. doi:10.1016/j.respol.2011.05.010.

Clarysse, B., M. Wright, A. Lockett, E. Van de Velde, and A. Vohora. 2005. "Spinning Out New Ventures: A Typology of Incubation Strategies from European Research Institutions." Journal of Business Venturing 20 (2): 183-216. doi:10.1016/j.jbusvent.2003.12.004.

Cools, E., and H. van Den Broeck. 2007. “Development and Validation of the Cognitive Style Indicator." Journal of Psychology 141 (4): 359-87.

Costa, J. P. T., and R. R. McCrae. 1985. The NEO Personality Inventory Manual. Odessa, FL: Psychological Assessment Resources.

Davis, A. E., and K. G. Shaver. 2009. In New Firm Creation in the United States: Initial Explorations with the PSED II Data Set, New York, NY US: Springer Social Motives in the PSED II edited by P. D. Reynolds and R. T. Curtin, 19-34.

Deci, E. L., A. H. Olafsen, and R. M. Ryan. 2017. "Self-Determination Theory in Work Organizations: The State of a Science." Annual Review of Organizational Psychology and Organizational Behavior 4: 19-43. doi:10.1146/annurev-orgpsych-032516-113108.

Deci, E. L., and R. M. Ryan. 1980. "The Empirical Exploration of Intrinsic Motivational Processes." In Advances in Experimental Social Psychology, Vol. 13, edited by L. Berkowitz, 39-80. New York, NY US: Academic Press.

Delmar, F., and ]. Wiklund. 2008. “The Effect of Small Business Managers' Growth Motivation on Firm Growth: A Longitudinal Study." Entrepreneurship: Theory \& Practice 32 (3): 437-57. doi:10.1111/j.1540-6520.2008.00235.x.

Di Gregorio, D., and S. Shane. 2003. “Why Do Some Universities Cenerate More Start-Ups than Others?” Research Policy 32 (2): 209.

Douglas, E. J. 2013. "Reconstructing Entrepreneurial Intentions to Identify Predisposition for Growth." Journal of Business Venturing 28 (5): 633-51. doi:10.1016/j.jbusvent.2012.07.005.

Fayolle, A., and F. Liñán. 2014. "The Future of Research on Entrepreneurial Intentions." Journal of Business Research 67 (5): 663-66. doi:10.1016/j.jbusres.2013.11.024.

Fini, R., R. Crimaldi, S. Santoni, and M. Sobrero. 2011. “Complements or Substitutes? the Role of Universities and Local Context in Supporting the Creation of Academic Spin-Offs." Research Policy 40 (8): 1113-27. doi:10.1016/j.respol.2011.05.013.

Frid, C. 2018. Publications Based on the Panel Study of Entrepreneurial Dynamics. Retrieved from http://www.psed.isr.umich.edu/psed/documentation 
Gartner, W. B., K. G. Shaver, N. M. Carter, and P. D. Reynolds. 2004. Handbook of Entrepreneurial Dynamics: The Process of Business Creation. Thousand Oaks, CA US: Sage Publications.

Gatewood, E. J. 2004. “Entrepreneurial Expectancies." In Handbook of Entrepreneurial Dynamics: The Process of Business Creation, edited by W.B. Gartner, K.C. Shaver, N.M. Carter, and P.D. Reynolds, 153-62. Thousand Oaks, CA US: Sage Publications.

Gatewood, E. J., K. G. Shaver, J. B. Powers, and W. B. Gartner. 2002. “Entrepreneurial Expectancy, Task Effort, and Performance." Entrepreneurship Theory \& Practice 27 (2): 187-206.

Ceuna, A., and F. Rossi. 2011. “Changes to University IPR Regulations in Europe and the Impact on Academic Patenting." Research Policy 40 (8): 1068-76. doi:10.1016/j.respol.2011.05.008.

Goethner, M., M. Obschonka, R. K. Silbereisen, and U. Cantner. 2012. “Scientists' Transition to Academic Entrepreneurship: Economic and Psychological Determinants." Journal of Economic Psychology 33 (3): 628-41. doi:10.1016/j.joep.2011.12.002.

Crimaldi, R., M. Kenney, D. S. Siegel, and M. Wright. 2011. "30 Years after Bayh-Dole: Reassessing Academic Entrepreneurship." Research Policy 40 (8): 1045-57. doi:10.1016/j.respol.2011.04.005.

Guerrero, M., and D. Urbano. 2014. “Academics' Start-Up Intentions and Knowledge Filters: An Individual Perspective of the Knowledge Spillover Theory of Entrepreneurship." Small Business Economics 43 (1): 57-74. doi:10.1007/s11187-013-9526-4.

Guerrero, M., D. Urbano, A. Fayolle, M. Klofsten, and S. Mian. 2016. “Entrepreneurial Universities: Emerging Models in the New Social and Economic Landscape." Small Business Economics 47 (3): 551-63. doi:10.1007/s11187-016-9755-4.

Gurdon, M. A., and K. J. Samsom. 2010. "A Longitudinal Study of Success and Failure among Scientist-Started Ventures." Technovation 30 (3): 207-14. doi:10.1016/j.technovation.2009.10.004.

Hsu, D. K., J. Wiklund, and R. D. Cotton. 2017. "Success, Failure, and Entrepreneurial Reentry: An Experimental Assessment of the Veracity of Self-Efficacy and Prospect Theory." Entrepreneurship: Theory \& Practice 41 (1): 19-47. doi:10.1111/etap.12166.

Hyman, H. 1942. The Psychology of Status. Archives of Psychology(No. 269).

Iorio, R., S. Labory, and F. Rentocchini. 2017. "The Importance of Pro-Social Behaviour for the Breadth and Depth of Knowledge Transfer Activities: An Analysis of Italian Academic Scientists." Research Policy 46 (2): 497-509. doi:10.1016/j.respol.2016.12.003.

Jain, S., G. George, and M. Maltarich. 2009. "Academics or Entrepreneurs? Investigating Role Identity Modification of University Scientists Involved in Commercialization Activity." Research Policy 38 (6): 922-35. doi:10.1016/j.respol.2009.02.007.

Judge, T. A., and J. E. Bono. 2001. "Relationship of Core Self-Evaluations Traits—Self-Esteem, Ceneralized Self-Efficacy, Locus of Control, and Emotional Stability—With Job Satisfaction and Job Performance: A Meta-Analysis." Journal of Applied Psychology 86 (1): 80-92. doi:10.1037/0021-9010.86.1.80.

Kaiser, J. (2017).2018 Some Scientists Hate NIH's New Definition of a Clinical Trial. Here's Why.

Kalar, B., and B. Antoncic. 2015. “The Entrepreneurial University, Academic Activities and Technology and Knowledge Transfer in Four European Countries." Technovation 36/37: 1-11. doi:10.1016/j.technovation.2014.11.002.

Kaltman, J. R., F. J. Evans, N. S. Danthi, C. O. Wu, D. M. DiMichele, and M. S. Lauer. 2014. Prior Publication Productivity, Grant Percentile Ranking, and Topic-Normalized Citation Impact of NHLBI Cardiovascular Ro1 Crants. Circulation Research 115 (7): 617-62.

Kelley, H. H. 1952. "The Two Functions of Reference Groups." In Readings in Social Psychology, 2 ed. edited by G.E. Swanson, T.M. Newcomb, and E.L. Hartley, 410-14. New York, NY US: Holt, Rinehart, \& Winston.

Kelman, H. C. 1961. “Processes of Opinion Change.” Public Opinion Quarterly 25: 57-78.

Kenney, M., and D. Patton. 2011. “Does Inventor Ownership Encourage University Research-Derived Entrepreneurship? A Six University Comparison." Research Policy 40 (8): 1100-12. doi:10.1016/j.respol.2011.05.012.

Knockaert, M., M. D. Foo, T. Erikson, and E. Cools. 2015. “Growth Intentions among Research Scientists: A Cognitive Style Perspective.” Technovation 38: 64-74. doi:10.1016/j.technovation.2014.12.001.

Kolvereid, L. 1996. “Organizational Employment Vs. Self-Employment: Reasons for Career Choice Intentions.” Entrepreneurship Theory \& Practice 20 (3): $23-31$.

Krabel, S., and P. Mueller. 2009. “What Drives Scientists to Start Their Own Company?: An Empirical Investigation of Max Planck Society Scientists." Research Policy 38 (6): 947-56. doi:10.1016/j.respol.2009.02.005.

Krueger Jr, N. F. 2017. “Is Research on Entrepreneurial Intentions Growing? or ... Just Getting Bigger?” In Revisiting the Entrepreneurial Mind. Inside the Black Box: An Expanded Edition, edited by M. Brännback, and A.L. Carsrud, 35-40. Switzerland: Springer International Publishing Switzerland.

Lam, A. 2011. “What Motivates Academic Scientists to Engage in Research Commercialization: 'Cold', 'Ribbon' or 'Puzzle'?” Research Policy 40 (10): 1354-68. doi:10.1016/j.respol.2011.09.002.

Lepper, M. R., J. Henderlong, and I. Gingras. 1999. “Understanding the Effects of Extrinsic Rewards on Intrinsic motivation-Uses and Abuses of Meta-Analysis: Comment on Deci, Koestner, and Ryan (1999)." Psychological Bulletin 125 (6): 669-76. doi:10.1037/0033-2909.125.6.669.

Liñán, F., and Y.-W. Chen. 2009. "Development and Cross-Cultural Application of a Specific Instrument to Measure Entrepreneurial Intentions." Entrepreneurship: Theory \& Practice 33 (3): 593-617. doi:10.1111/j.1540-6520.2009.00318.x.

Link, A. N., D. S. Siegel, and B. Bozeman. 2007. “An Empirical Analysis of the Propensity of Academics to Engage in Informal University Technology Transfer." Industrial \& Corporate Change 16 (4): 641-55.

Link, A. N., D. S. Siegel, and D. D. Van Fleet. 2011. “Public Science and Public Innovation: Assessing the Relationship between Patenting at U.S. National Laboratories and the Bayh-Dole Act." Research Policy 40 (8): 1094-99. doi:10.1016/j.respol.2011.05.011.

Lortie, J., and C. Castogiovanni. 2015. "The Theory of Planned Behavior in Entrepreneurship Research: What We Know and Future Directions." International Entrepreneurship and Management Journal 11 (4): 935-57. doi:10.1007/s11365-015-0358-3.

Manolova, T. S., C. C. Brush, L. F. Edelman, and K. C. Shaver. 2012. “One Size Does Not Fit All: Entrepreneurial Expectancies and Growth Intentions of US Women and Men Nascent Entrepreneurs." Entrepreneurship \& Regional Development 24 (1/2): 7-27. doi:10.1080/08985626.2012.637344.

Merton, R. K. 1957. Social Theory and Social Structure. New York, NY US: Free Press.

Miranda, F. J., A. Chamorro, and S. Rubio. 2017. Determinants of the Intention to Create a Spin-Off in Spanish Universities. International Journal of Entrepreneurship \& Innovation Management 21 (4/5): 299-317. 
Mosey, S., and M. Wright. 2007. “From Human Capital to Social Capital: A Longitudinal Study of Technology-Based Academic Entrepreneurs." Entrepreneurship: Theory \& Practice 31 (6): 909-35. doi:10.1111/j.1540-6520.2007.00203.X.

Mosey, S., M. Wright, and B. Clarysse. 2012. "Transforming Traditional University Structures for the Knowledge Economy through Multidisciplinary Institutes." Cambridge Journal of Economics 36 (3): 587-607.

Newman, Alexander, Martin Obschonka, Susan Schwarz, Michael Cohen, and Ingrid Nielsen. 2019. Entrepreneurial Self-Efficacy: A Systematic Review of the Literature on Its Theoretical Foundations, Measurement, Antecedents, and Outcomes, and an Agenda for Future Research. Journal of Vocational Behavior 110, no. (Part B): 403-419.

Nicolaou, N., and S. Birley. 2003. "Academic Networks in a Trichotomous Categorisation of University Spinouts." Journal of Business Venturing 18 (3): 333-59. doi:10.1016/S0883-9026(02)00118-0.

Nicolaou, N., and V. Souitaris. 2016. “Can Perceived Support for Entrepreneurship Keep Great Faculty in the Face of Spinouts?” Journal of Product Innovation Management 33 (3): 298-319. doi:10.1111/jpim.12274.

Norman, G. 2010. “Likert Scales, Levels of Measurement, and the 'Laws' of Statistics.” Advances in Health Science Education 15: 625-32.

Nunnally, J. C. 1978. Psychometric Theory, 2nd ed. New York, NY US: McGraw-Hill.

Obschonka, M., and M. Stuetzer. 2017. "Integrating Psychological Approaches to Entrepreneurship: The Entrepreneurial Personality System (EPS)." Small Business Economics 49 (1): 203-31. doi:10.1007/s11187-016-9821-y.

Owen-Smith, J., and W. W. Powell. 2001. "To Patent or Not: Faculty Decisions and Institutional Success at Technology Transfer." Journal of Technology Transfer 26 (1-2): 99-114.

Prodan, I., and M. Drnovsek. 2010. “Conceptualizing Academic-Entrepreneurial Intentions: An Empirical Test.” Technovation 30 (5/6): $332-47$. doi:10.1016/j.technovation.2010.02.002.

Rauch, A., and M. Frese. 2007. "Born to Be an Entrepreneur? Revisiting the Personality Approach to Entrepreneurship." In The Psychology of Entrepreneurship, edited by J.R. Baum, M. Frese, and R.A. Baron, 41-65. Mahwah, N] US: Lawrence Erlbaum Associates.

Renko, M., K. Kroeck, and A. Bullough. 2012. “Expectancy Theory and Nascent Entrepreneurship.” Small Business Economics 39 (3): 667-84. doi:10.1007/s11187-011-9354-3.

Reynolds, P. D. 2018. Business Creation: Ten Factors for Entrepreneurial Success. Cheltenham, UK: Edward Elgar.

Reynolds, P. D., and R. T. Curtin, Eds. 2009. New Firm Creation in the United States: Initial Explorations with the PSED II Data Set. New York, NY US: Springer.

Reynolds, P. D., and R. T. Curtin. 2011. “PSED I, II Harmonized Transitions, Outcomes Data Set.” Retrieved from http://www.psed.isr.umich.edu/psed/data

Ries, E. 2011. The Lean Startup: How Today's Entrepreneurs Use Continuous Innovation to Create Radically Successful Businesses, New York, NY: Crown Business.

Robinson, P. B., D. V. Stimpson, J. C. Huefner, and H. K. Hunt. 1991. “An Attitude Approach to the Prediction of Entrepreneurship.” Entrepreneurship: Theory \& Practice 15 (4): 13-31.

Scheinberg, S., and I. C. Macmillan. 1988. "An 11 Country Study of Motivations to Start a Business.” In Frontiers of Entrepreneurship Research 1988, edited by B.A. Kirchhoff, W.A. Long, W.E. McMullan, K.H. Vesper, and W.E.W. Jr, 669-87. Babson Park, MA US: Babson College.

Schjoedt, L. 2018. "Implementation Intentions: The When, Where, and How of Entrepreneurial Intentions" Influence on Behavior." In A Research Agenda for Entrepreneurial Cognition and Intention, edited by M. Brännback, and A.L. Carsrud, 105-21. Northampton, MA: Edward Elgar Publishing.

Schlaegel, C., and M. Koenig. 2014. “Determinants of Entrepreneurial Intent: A Meta-Analytic Test and Integration of Competing Models." Entrepreneurship: Theory \& Practice 38 (2): 291-332. doi:10.1111/etap.12087.

Shannahan, K., A. Bush, and R. Shannahan. 2013. “Are Your Salespeople Coachable? How Salesperson Coachability, Trait Competitiveness, and Transformational Leadership Enhance Sales Performance." Journal of the Academy of Marketing Science 41 (1): 40-54. doi:10.1007/s11747-012-0302-9.

Shapero, A., and L. Sokol. 1982. Social Dimensions of Entrepreneurship. In Encyclopedia of Entrepreneurship, edited by C. A. Kent, D. L. Sexton, and K. H. Vesper, 72-90. Englewood Cliffs, N] US: Prentice-Hall.

Shaver, K. G., C. A. Blair, and A. E. Davis. 2014. “The Embedded Entrepreneur: Gender, Family Stage, and Psychological Correlates of Start-Up Success and Failure." Paper presented at the Diana International Research Conference, Stockholm, Sweden.

Stajkovic, A. D., and F. Luthans. 1998. "Self-Efficacy and Work-Related Performance: A Meta-Analysis." Psychological Bulletin 124 (2): $240-61$. doi:10.1037/0033-2909.124.2.240.

Stevenson, H. H., and J. C. Jarillo. 1990. “A Paradigm of Entrepreneurship: Entrepreneurial Management." Strategic Management Journal 11 (4): 17-27.

Stevenson, H. H., M. J. Roberts, and H. I. Grousbeck. 1989. New Business Ventures and the Entrepreneur. Homewood, IL US: Irwin.

Stuart, T. E., and W. W. Ding. 2006. "When Do Scientists Become Entrepreneurs? the Social Structural Antecedents of Commercial Activity in the Academic Life Sciences." American Journal of Sociology 112 (1): 97-144.

Tartari, V., M. Perkmann, and A. Salter. 2014. "In Cood Company: The Influence of Peers on Industry Engagement by Academic Scientists." Research Policy 43 (7): 1189-203. doi:10.1016/j.respol.2014.02.003.

Thursby, J. G., and M. C. Thursby. 2011a. “Faculty Participation in Licensing: Implications for Research.” Research Policy 40 (1): $20-29$. doi:10.1016/j.respol.2010.09.014.

Thursby, J. G., and M. C. Thursby. 2011b. “Has the Bayh-Dole Act Compromised Basic Research?” Research Policy 40 (8): $1077-83$. doi:10.1016/j.respol.2011.05.009.

van Burg, E., and K. E. van Oorschot. 2013. “Cooperating to Commercialize Technology: A Dynamic Model of Fairness Perceptions, Experience, and Cooperation." Production \& Operations Management 22 (6): 1336-55. doi:10.1111/j.1937-5956.2012.01331.X.

Vroom, V. H. 1964. Work and Motivation. New York, NY US: Wiley.

Wilson, F. 2008. "Venture Fund Economics: Allocating Follow-On Capital." Retrieved from https://avc.com/2008/08/venture-fund-3/.

Windle, G. 2011. "What Is Resilience? A Review and Concept Analysis." Reviews in Clinical Cerontology 21 (2): 152-69.

doi:10.1017/S0959259810000420. 
Wu, Y., E. W. Welch, and W.-L. Huang. 2015. “Commercialization of University Inventions: Individual and Institutional Factors Affecting Licensing of University Patents." Technovation 36/37: 12-25. doi:10.1016/j.technovation.2014.09.004.

Zhang, J. 2009. “Why Do Some US Universities Cenerate More Venture-Backed Academic Entrepreneurs than Others?” Venture Capital 11 (2): 133-62. doi:10.1080/13691060802525270. 